\title{
Editorial
}

\section{Corona kills corona: convalescent sera option for global war against corona virus disease 2019}

\author{
Babita $^{1 *}$, Anita Punia ${ }^{1}$, S. K. Jha ${ }^{1}$, Mahavir Jangra² \\ ${ }^{1}$ Department of Community Medicine, BPS Govt. Medical College for Women, Khanpur Kalan, Sonepat, Haryana, \\ India \\ ${ }^{2}$ Department of General Surgery, Pandit Bhagwat Dayal Sharma Post Graduate Institute of Medical Sciences, Rohtak, \\ Haryana, India
}

Received: 20 March 2020

Accepted: 31 March 2020

\author{
*Correspondence: \\ Dr. Babita, \\ E-mail: drbabitajangra@gmail.com
}

Copyright: () the author(s), publisher and licensee Medip Academy. This is an open-access article distributed under the terms of the Creative Commons Attribution Non-Commercial License, which permits unrestricted non-commercial use, distribution, and reproduction in any medium, provided the original work is properly cited.

On December 31 2019 China reported first case of atypical pneumonia in Wuhan, the capital of Hubei province. The causative virus was found to be a beta coronavirus, closely related to the severe acute respiratory syndrome coronavirus (SARS-CoV-1) from 2003 and similar to Sarbeco viruses isolated from bats. ${ }^{1,2}$ It was therefore termed SARS-CoV-2 and the disease was named corona virus disease 2019 (COVID-19). ${ }^{3}$ The outbreak in Wuhan expanded quickly and led to the lockdown of Wuhan and other parts of China. While the lockdown, at least temporarily, brought the situation under control in China, but SARS-CoV-2 spread globally causing a pandemic with more than 4 lakh infections and about 19000 fatalities (as of March 25, 2020). Nucleic acid tests that detect the SARS-CoV-2 RNA genome were quickly developed and are now widely employed to diagnose COVID-19.,

There is an urgent need to have practical and effective interventional approaches to reduce the impact of COVID-19. At this point, frontline healthcare workers are working in a very high risk setting and they need to be armed with effective weapons to combat this deadly virus. One unique resource that has not received enough attention is convalescent whole blood or plasma from patients who have recovered from COVID-19. Passive vaccination with high titer immune sera or commercially prepared polyclonal antibodies has been used successfully in the history of vaccination. In the 1930s, convalescent human sera were used for the treatment of measles and yellow fever. ${ }^{6,7}$ Convalescent human plasma was somewhat successful in treating patients of the great influenza pandemic of $1918 .^{8}$ More recently, the use of convalescent plasma to treat patients with $\mathrm{H} 1 \mathrm{~N} 1$ flu has been reported to decrease mortality. ${ }^{9}$ In the twenty-first century, there have been two other epidemics with coronaviruses that were associated with high mortality, SARS1 in 2003 and Middle East respiratory syndrome (MERS) in 2012. The SARS1 epidemic was contained, but MERS became endemic in the Middle East and triggered a secondary major outbreak in South Korea. In both outbreaks, the high mortality and absence of effective therapies led to the use of convalescent serum. The largest study involved the treatment of 80 patients with SARS in Hong Kong. Patients treated before day 14 had improved prognosis consistent with the notion that earlier administration is more likely to be effective. ${ }^{10}$

More than one lakh people throughout the world have survived after SARS-CoV-2 infection till date. Their blood or plasma could be a very powerful weapon to provide highly effective treatment to people who are actively infected with Corona. As more individuals contract COVID-19 and recover, the number of potential donors will continue to increase. Blood from those patients who survived with general supportive care only are of particular importance. It will take a considerable amount of time to prove that the vaccines and drugs currently under development are effective and for them to become widely available despite accelerated programs. In addition, the assay could be used to screen health care workers to allow selective deployment of immune 
medical personnel to care for patients with COVID-19. Such a strategy would likely limit nosocomial spread of the virus. ${ }^{11-13}$

However, there remains a great need for laboratory assays that measure antibody responses and determine seroconversion. While such serological assays are not well suited to detect acute infections, they support to a number of highly relevant applications. First, serological assays will allow for the identification of individuals who mounted strong antibody responses and who could serve as donors for the generation of convalescent serum therapeutics. Second, serological assays allow us to study the immune response(s) to SARS-CoV-2 in dynamic qualitative and quantitative manner. Third, sero surveys are needed to determine the precise rate of infection in an affected area, which is an essential variable to accurately determine the infection fatality rate. Lastly, serological assays will permit to determine who is immune and who is not.

Natural viral infection is more capable of eliciting and maintaining high-level antibody responses compared to vaccination as shown previously. ${ }^{14}$ WHO and national health authorities of all affected countries by the pandemic should plan well-organized activities to expand this passive therapy program to establish a national central coordinating office to implement the above guideline; to establish special criteria and process related to this program; collaboration with international experts in blood transfusion and passive immune therapy would allow for the establishment of a standardized blood collection and processing procedure that can be used in qualified medical and blood transfusion facilities; to stockpile and coordinate the use of collected and processed convalescent whole blood and plasma samples; to train all the healthcare workers on the appropriate use of these treatments to clinically-indicated COVID-19 patients; to use convalescent sera for therapeutic and prophylactic use among healthcare workers as they are important fighters in this war against corona, to recruit and educate COVID-19 survivors for their participation in this program; to establish a database on the source, use, and outcome of such treatment; to save a small aliquot from each convalescent sample for subsequent in-depth immunological analysis, including corona specific antibody titers and specificity of neutralizing antibody activities.

Such a national program in affected countries can be established through financial and technical collaborations with international organizations and groups with greater technical expertise. Data learned from such programs will provide highly useful information for the development of vaccines and monoclonal antibody based treatment. This is critical in breaking the chain of continued viral transmission and a stop gap treatment to achieve ultimate control of the current corona pandemic over the globe.

\section{REFERENCES}

1. Wu F, Zhao S, Yu B, Chen YM, Wang W, Song $\mathrm{ZG}$, et al. A new coronavirus associated with human respiratory disease in China. Nature. 2020;579(7798):265-9.

2. Zhou P, Yang XL, Wang XG, Hu B, Zhang L, Zhang $\mathrm{W}$, et al. A pneumonia outbreak associated with a new coronavirus of probable bat origin. Nature. 2020;3:1-4.

3. Gorbalenya AE, Baker SC, Baric RS. The species Severe acute respiratory syndrome-related 291 coronavirus: classifying 2019-nCoV and naming it SARS-CoV-2. Nat Microbiol. 2020;2:1-9.

4. Chu DKW, Pan Y, Cheng SMS, Hui KPY, Krishnan P, Liu Y, et al. Molecular Diagnosis of a Novel Coronavirus (2019-nCoV) Causing an Outbreak of Pneumonia. Clin Chem. 2020;66(4):549-55.

5. Corman VM, Landt O, Kaiser M, Molenkamp R, Meijer A, Chu DKW, et al. Detection of 2019 novel coronavirus (2019-nCoV) by real time RT-PCR. Euro Surveill. 2020;25(3):2000045.

6. Sawyer LA. Antibodies for the prevention and treatment of viral diseases. Antivrial Res. 2000;47:57-77.

7. Lachmann PJ. The use of antibodies in the prophylaxis and treatment of infections. Emerg Microbes Infect. 2012;1:e11.

8. Luke TC, Kilbane EM, Jackson JL, Hoffman SL. Meta-analysis: convalescent blood products for Spanish influenza pneumonia: a future $\mathrm{H} 5 \mathrm{~N} 1$ treatment. Ann Intern Med. 2006;145:599-609.

9. Huang IF, To KK, Lee CK, Lee KL, Chan K, Yan WW, et al. Convalescent plasma treatment reduced mortality in patients with severe pandemic influenza A (H1N1) 2009 virus infection. Clin Infect Dis. 2011;52:447-56.

10. Cheng Y, Wong R, Soo YO, Wong WS, Lee CK, $\mathrm{Ng} \mathrm{MH}$, et al. Use of convalescent plasma therapy in SARS patients in Hong Kong. Eur J Clin Microbiol Infect Dis. 2005;24(1):44-6.

11. Letko M, Marzi A, Munster V. Functional assessment of cell entry and receptor usage for SARS CoV-2 and other lineage B betacoronaviruses. Nat Microbiol. 2020;5(4):562-9.

12. Wrapp D, Wang N, Corbett KS, Goldsmith JA, Hsieh CL, Abiona O, et al. Cryo-EM structure of the 2019-nCoV spike in the prefusion conformation. Science. 2020;367(6483):1260-3.

13. Walls AC, Park YJ, Tortorici MA, Wall A, McGuire AT, Veesler D. Structure, Function, and Antigenicity of the SARS-CoV-2 Spike Glycoprotein. Cell. 2020.

14. Amanna IJ, Carlson NE, Slifka MK. Duration of humoral immunity to common viral and vaccine antigens. N Engl J of Med. 2007;8;357(19):1903-15.

Cite this article as: Babita, Punia A, Jha SK, Jangra M. Corona kills corona: convalescent sera option for global war against corona virus disease 2019. Int J Community Med Public Health 2020;7:2001-2. 